\title{
Mantle dynamics and characteristics of the Azores plateau
}

\author{
C. Adam ${ }^{\mathrm{a}, *}$, P. Madureira ${ }^{\mathrm{a}, \mathrm{b}}$, J.M. Miranda ${ }^{\mathrm{c}}$, N. Lourenço ${ }^{\mathrm{c}, \mathrm{d}}$, M. Yoshida ${ }^{\mathrm{e}}$, D. Fitzenz ${ }^{\mathrm{a}, 1}$ \\ ${ }^{a}$ Centro de Geofisica de Évora/Univ. Évora, 7002-554 Évora, Portugal \\ b Estrutura de Missão para a Extensão da Plataforma Continental (EMEPC), 2770-047, Paço d' Arcos, Portugal \\ ${ }^{\mathrm{c}}$ Instituto Portugues do Mar e da Atmosfera, Lisboa, Portugal \\ ${ }^{\mathrm{d}}$ University of Algarve, IDL, Campus de Gambelas, 8000 Faro, Portugal \\ e Institute for Research on Earth Evolution (IFREE), Japan Agency for Marine-Earth Science and Technology (JAMSTEC), Yokosuka, Kanagawa 237-0061, Japan
}

\section{A R T I C L E I N F O}

\section{Article history:}

Received 25 July 2012

Received in revised form

2 November 2012

Accepted 5 November 2012

Editor: T. Spohn

Available online 18 January 2013

Keywords:

Azores triple junction

mantle dynamics

dynamic topography

lithospheric stresses

tectonic regimes

\begin{abstract}
A B S T R A C T
Situated in the middle of the Atlantic Ocean, the Azores plateau is a region of elevated topography encompassing the triple junction between the Eurasian, Nubian and North American plates. The plateau is crossed by the Mid-Atlantic Ridge, and the Terceira Rift is generally thought of as its northern boundary. The origin of the plateau and of the Terceira Rift is still under debate. This region is associated with active volcanism. Geophysical data describe complex tectonic and seismic patterns. The mantle under this region is characterized by anomalously slow seismic velocities. However, this mantle structure has not yet been used to quantitatively assess the influence of the mantle dynamics on the surface tectonics. In this study, we use a highly resolved tomography model to model the convection occurring in the mantle beneath the Azores region. The convection pattern points out two distinct upwelling, thus proving that the volcanism emplacement is created by a buoyant mantle upwelling. The modeled dynamic topography recovers well the characteristics of the depth anomaly associated with the Azores plateau, except for the south-eastern most part, thus proving that most of the depth anomaly associated with the Azores plateau is created by the present-day mantle dynamics. The stresses induced by the mantle convection can account for the rifting regime observed over the Azores plateau and the Terceira Rift, and its consequences in terms of surface morphology and seismicity.
\end{abstract}

(c) 2012 Elsevier B.V. All rights reserved.

\section{Introduction}

The Azores plateau, a region of elevated topography (Fig. 1), encompasses the boundary zone where three major tectonic plates Eurasia, Nubia and North America meet to form the Azores Triple Junction. The plateau is asymmetric relative to the Mid-Atlantic Ridge (MAR). The eastern side of the plateau, the zone our study focuses on, has an approximate triangular shape. It is delimited by two major tectonic discontinuities: the Mid-Atlantic Ridge (MAR) to the west, and the Terceira Rift (TR) to the north-east. The East Azores fracture Zone constitutes its southern boundary. It contains numerous seamounts and seven of the Azores islands: Faial, Pico, S. Jorge, Graciosa and Terceira for the central group, S. Miguel and S. Maria in the eastern group.

Several hypotheses were proposed for the plateau formation. Some invoke only a tectonic origin. The enhanced upwelling and magmatism would then be driven by plate-boundary forces. Luis et al. (1994) show that there has been a northward jump of the

\footnotetext{
${ }^{*}$ Corresponding author.

E-mail address: adam@uevora.pt (C. Adam).

${ }^{1}$ Now at RMS, Inc, Newark, CA, USA
}

Azores triple junction, during which the Azores region would have been transferred from the Nubian plate to the Eurasian plate. Luis et al. (1994) think that this mechanism is the result of small changes in the relative motion between the three megaplates. They also considered that this mechanism would be responsible for the "disturbed" topography. For Luis and Neves (2006), the elevation of the Azores plateau is mainly due to thickened crust, whereas the presence of buoyant material at the base of the crust is also required to partially account for the uplift of the plateau.

For others, the presence of the Azores plume is necessary to explain the observations. For example, Yang et al. (2006) agree with the jump of the Azores triple junction but argue that the latter is triggered by the relative motion between the lithospheric plate and an underlying mantle plume. Vogt and Jung (2004) also mention the role of the plume in the plateau formation. This later would have been formed by successive NE jumps of the oblique spreading axis, where the present TR is the latest stage. For Gente et al. (2003), the plateau results from the interaction between the MAR and the plume, followed by the progressive southward rifting of the plateau after $7 \mathrm{Ma}$. According to different authors the beginning of the enhanced volcanism occurred around $10 \mathrm{Ma}$, and ended between 3 and 7 Ma depending upon latitude (Cannat et al., 1999; Escartín et al., 2001; Gente et al., 2003; Maia et al., 